\title{
Pseudotachylytes, related fault rocks, asperities, and crustal structures in the Hidaka metamorphic belt, Hokkaido, northern Japan
}

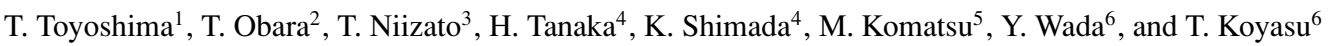 \\ ${ }^{1}$ Graduate School of Science and Technology, Niigata University, Niigata 950-2181, Japan \\ ${ }^{2}$ Japan Oil Development Co., Ltd., Tokyo 104-0033, Japan \\ ${ }^{3}$ Horonobe Underground Research Center, Japan Nuclear Cycle Development Institute, Horonobe, Hokkaido 098-3297, Japan \\ ${ }^{4}$ Department of Earth and Planetary Science, Graduate School of Science, the University of Tokyo, Tokyo 113-0033, Japan \\ ${ }^{5}$ Department of Earth Science, Ehime University, Matsuyama 790-8577, Japan \\ ${ }^{6}$ Department of Geology, Niigata University, Niigata 950-2181, Japan
}

(Received June 5, 2004; Revised November 20, 2004; Accepted December 3, 2004)

\begin{abstract}
Many pseudotachylytes and their related fault rocks are found in the Hidaka metamorphic belt representing an ancient crustal section. On the basis of field observations of the pseudotachylytes and related fault rocks, nature of seismogenic faulting in the Hidaka crust is examined. The field observations suggest the following conclusions. (1) Two structural types of pseudotachylytes are distinguished: layer-parallel and layer-oblique. The latter are scattered in the metamorphic belt, but the former occur only in the southern part of the metamorphic belt. (2) An abundance of the layer-parallel pseudotachylytes suggests that earthquakes occurred repeatedly and frequently in the southern part, where complicated and duplicated crustal structures occur with many lowtemperature thin mylonite zones. The southern part with such crustal structures was an ancient seismogenic area containing asperities and having a radius of a few tens of kilometers in the Hidaka crust. In the seismogenic area, the layer-parallel pseudotachylytes resulted from seismic slip on the mylonitic foliation within the lowtemperature mylonite zones with strong preferred orientation of micas. (3) The layer-parallel pseudotachylytes and the subsequent layer-oblique pseudotachylytes post-date the latest and very-low-temperature mylonitization in the metamorphic belt. The former pseudotachylytes formed just above the upper side of the brittle-plastic transition zone.
\end{abstract}

Key words: Pseudotachylyte, mylonite, cataclasite, asperity, earthquake, Hidaka metamorphic belt.

\section{Introduction}

The Hidaka metamorphic belt was revealed to represent an ancient crustal section of ca. $23 \mathrm{~km}$ thick (e.g. Komatsu et al., 1983). Many pseudotachylytes, mylonites, and cataclasites are found in the Hidaka crustal rocks (e.g. Toyoshima, 1991; Toyoshima et al., 1997).

Pseudotachylytes are commonly found in many crustal faults or shear zones in metamorphic belts and plutonic zones throughout the world (e.g. Sibson, 1975). There is no doubt that pseudotachylytes result from frictional melting and cataclastic deformation during seismic faulting (e.g. Sibson, 1975; Maddock, 1983, 1986). Analysis of fracture geometry accompanying pseudotachylyte generation may provide insight into kinematics of earthquake rupture process (Grocott, 1981; Swanson, 1988). Studies of the melting process are also important to determine the nature of frictional heating on fault planes and the behavior of faults during seismogenic faulting (Sibson, 1975, 1977; Allen, 1979; Maddock, 1983; Spray, 1987). Furthermore, an important role of the preferential melting of hydrous phases such as biotite or amphibole during the frictional melting has been argued for natural pseudotachylytes (e.g. Allen,

Copy right(c) The Society of Geomagnetism and Earth, Planetary and Space Sciences (SGEPSS); The Seismological Society of Japan; The Volcanological Society of Japan; The Geodetic Society of Japan; The Japanese Society for Planetary Sciences; TERRAPUB
1979; Maddock, 1983; Toyoshima, 1990) and for artificially produced pseudotachylytes (Spray, 1987).

Toyoshima (1990) has reported pseudotachylytes obliquely cutting metamorphic layering and mylonitic foliation of their host rocks in the Hidaka metamorphic belt. Besides the layer-oblique pseudotachylytes, still unreported layer-parallel pseudotachylytes are frequently found in the metamorphic belt. We will present distribution and process of formation of these pseudotachylytes on the basis of field observations, and infer nature of an ancient seismogenic slip area containing asperities in the Hidaka metamorphic belt.

\section{Geology and Tectonics of the Hidaka Metamor- phic Belt}

The Hidaka metamorphic belt is characterized by a N-S trending zonal arrangement of very low-grade to granulite facies metamorphic rocks and magmatic intrusives (e.g. Komatsu et al., 1983, 1986, 1989; Osanai, 1985; Osanai et al., 1986a, b; Fig. 1). The metamorphic grades increase westward (to the basal part of the crustal metamorphic sequence). The Hidaka metamorphic belt is bounded on the west by the Poroshiri ophiolite belt in the north and by the late Cretaceous to early Paleogene accretionary complex (Ueda et al., 1993) in the south (Fig. 1). The western boundary of the metamorphic belt is a large basal fault (Hidaka 


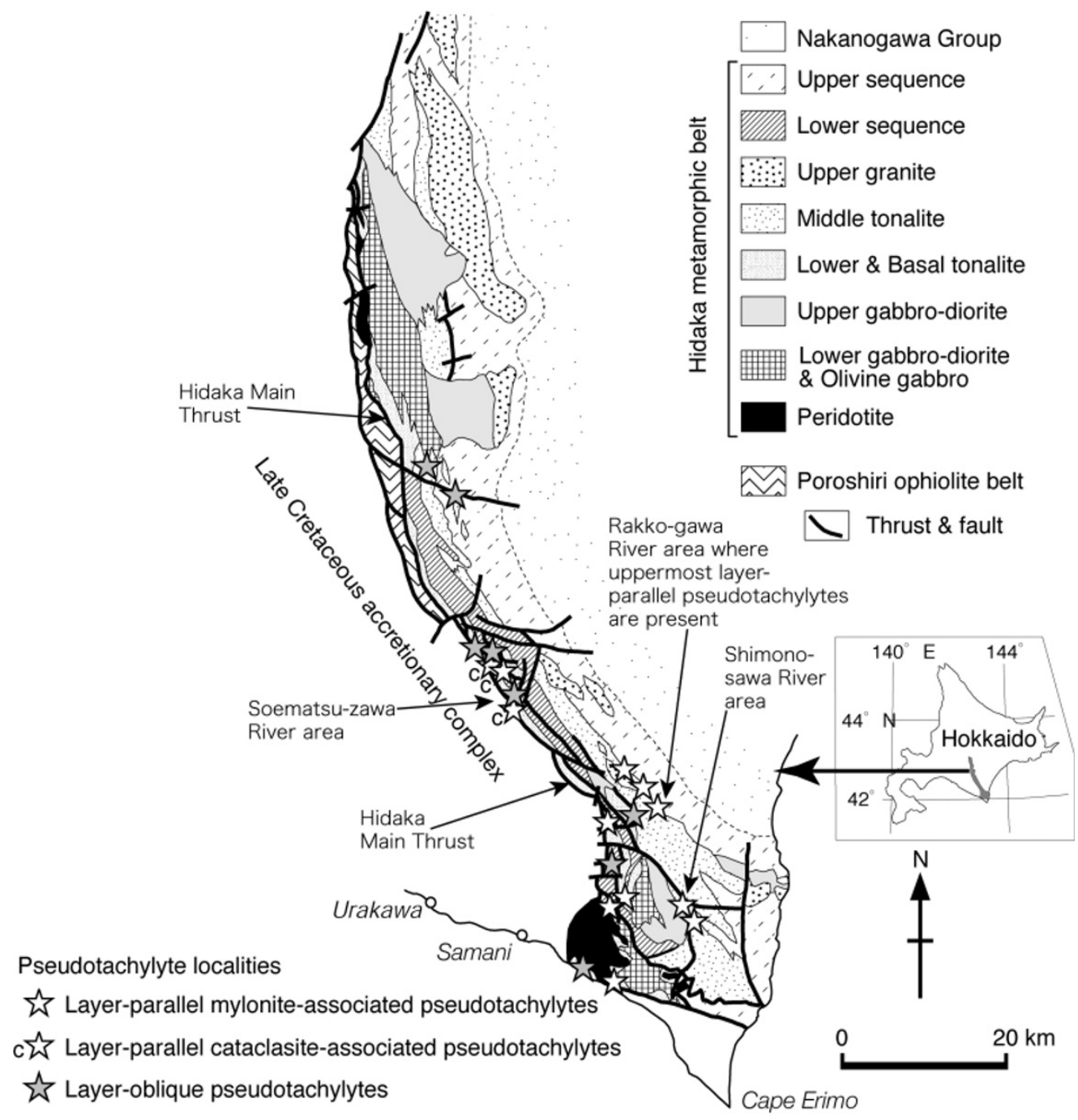

Fig. 1. Simplified geological map and pseudotachylyte distribution of the Hidaka metamorphic belt, compiled from Osanai et al. (1986a), Owada (1989), Toyoshima (1990), Shimura (1992), Toyoshima et al. (1994), Komatsu et al. (1994), Obara (1997), and Niizato and Toyoshima (2000).

Main Thrust; Fig. 1). Along the fault, the basal tonalite of the metamorphic belt are strongly deformed and retrogressively metamorphosed, giving rise to a N-S striking tonalite mylonite zone up to ca. $2 \mathrm{~km}$ wide (western-margin mylonite zone). The prominent foliations of the metamorphic rocks are steeply inclined to the east, except in the southern area of the metamorphic belt (Fig. 2). The Hidaka metamorphic belt is thought to be a tilted island-arc assembly of crustal layers developed during the early to middle Tertiary.

The tectonic evolution of the Hidaka metamorphic belt is divided into 3 stages based on the nature and sequence of deformation, metamorphism, and igneous activity during early Paleocene to Miocene time; I: formation of magmatic arc crust (Hidaka crust; $\mathrm{D}_{0}$ and $\mathrm{D}_{1}$ ), II: subhorizontal displacement and exhumation of the crust $\left(\mathrm{D}_{2}\right.$ and $\left.\mathrm{D}_{3}\right)$, and III: post-kinematic ductile and brittle deformations (e.g. Toyoshima et al., 1994, 1997; Obara and Toyoshima, 2000; Table 1). After the formation of the Hidaka crust during the $\mathrm{D}_{1}$-stage, top-to-the south subhorizontal displacement of detached lower to upper crustal rocks occurred along a basal detachment (decollement), resulting in the formation of duplex structures, high-temperature mylonitization, and S-type granitic intrusions $\left(\mathrm{D}_{2}\right)$. The decollement was formed along the transitional zone from amphibolite to granulite facies, from where partial melt fraction increased downward and fluid amounts decreased downward. The localization of intra-crustal decollement was structurally induced by the effect of multiplication of the two factors: melt fraction and fluid amounts. The upper part on the decollement was stronger and more brittle than the deeper part (Toyoshima et al., 1994). During the $\mathrm{D}_{2}$-stage, the $\mathrm{Hi}$ daka crustal rocks were in a flat-lying structural state and $\mathrm{D}_{2}$-mylnite zones were primarily formed subhorizontally at different crustal levels. The $\mathrm{D}_{2}$-major mylonite zones form with the thickness of a few hundreds of meters to $2 \mathrm{~km}$ in the basal part (western margin) of lower gabbro and the upper part (eastern margin) of lower sequence (Fig. 1). The Stype magma, which was squeezed and rose from the deeper levels of the crust, was intruded into the basal detachment (decollement; Toyoshima, 1991) and along floor, ramp, and 
Table 1. Tectonic and metamorphic history of the Hidaka metamorphic belt, modified from Toyoshima et al. (1997) and Obara and Toyoshima (2000). Relative temperature is metamorphic temperature conditions of the granulite unit.

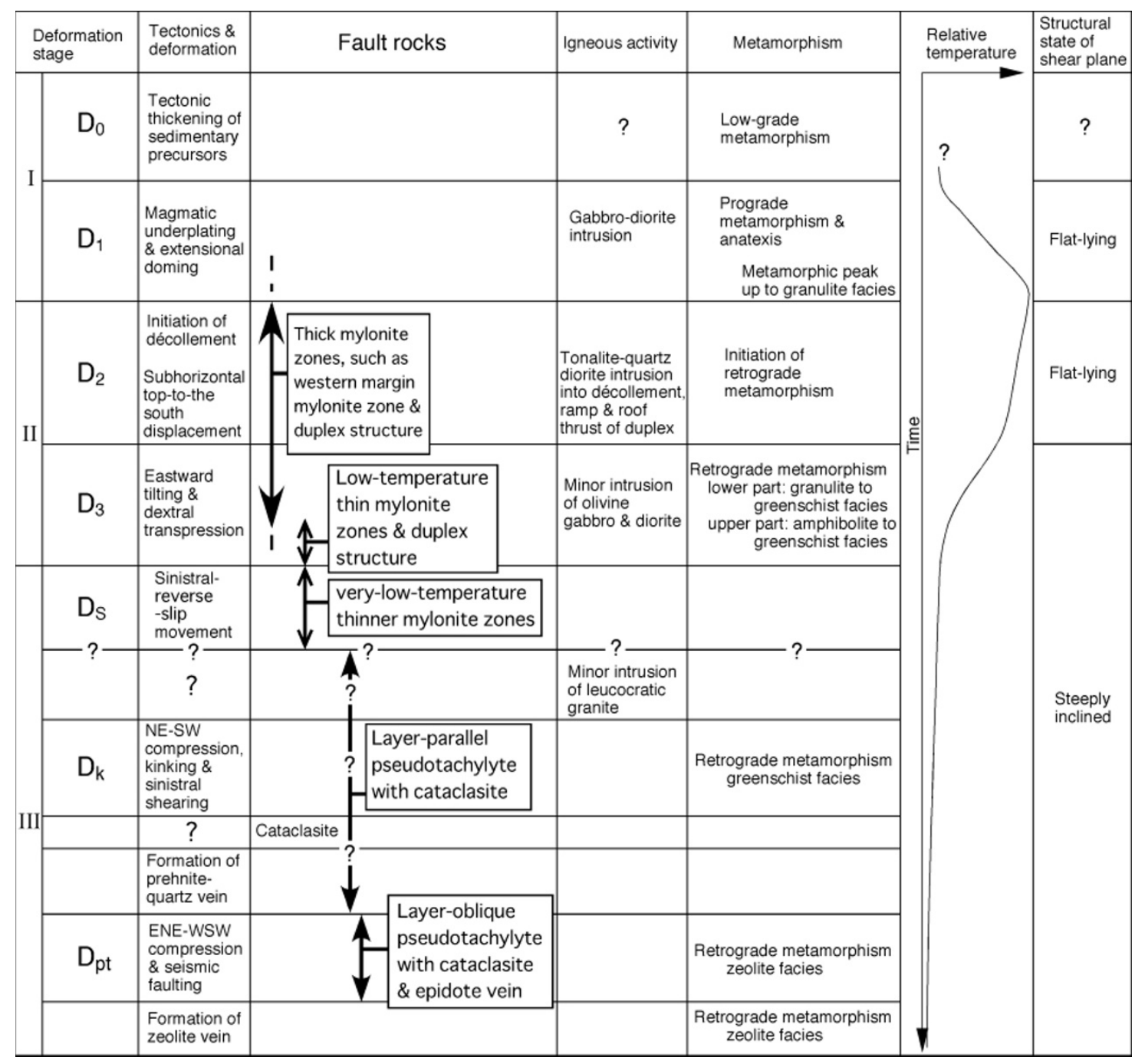

roof thrusts of a duplex structure (Shimura, 1992). Two giant intrusive sheets are formed as the basal and middle tonalities along the decollement and roof thrust in the later phase of the $\mathrm{D}_{2}$-stage (Fig. 1 and Table 1; Toyoshima, 1991; Toyoshima et al., 1994). Subsequently, $\mathrm{D}_{3}$-dextral transpression (dextral-reverse-slip movement) accompanied by retrograde mylonitization resulted in exhumation and eastward tilting of the Hidaka crustal rocks along a N-S to NW$\mathrm{SE}$ trending fault (Hidaka Main Thrust). The $\mathrm{D}_{2}$-mylonite zones and structures were inclined to vertical through the tilting during the $\mathrm{D}_{3}$-stage. The magmatic intrusions controlled and enhanced the structural break-forming tectonics (subhorizontal crustal movement) and subsequent exhumation in the $\mathrm{D}_{2}$ - and $\mathrm{D}_{3}$-stages (Toyoshima et al., 1994).

The major thick mylonite zones formed during the $\mathrm{D}_{3}$ stages are a few hundreds of meters to $2 \mathrm{~km}$ thick. Along the $\mathrm{D}_{3}$-thick mylonite zones, pre- $\mathrm{D}_{3}$-foliations of the surrounding rocks are strongly and widely dragged parallel to the centers of the zones (Fig. 2). The western-margin mylonite zone, the related mylonite zones, and their duplex structures resulted from the $\mathrm{D}_{3}$-tectonics, which induced strong preferred orientations of hydrous minerals in the $\mathrm{Hi}$ - daka crustal rocks under decreasing temperature conditions. In the southern part of the metamorphic belt, several sets of $\mathrm{D}_{3}$-related top-to-the southeast and dextral faults have induced duplication of the metamorphic rocks (Fig. 1; Arita et al., 1986; Owada, 1989; Toyoshima et al., 1997; Obara and Toyoshima, 2000). The southern part is characterized by the $\mathrm{D}_{3}$-structures such as the duplication, low-angle structures, duplex structures of the crustal rocks, and many thin mylonite zones (Obara and Toyoshima, 2000). The $\mathrm{D}_{3}$-thin mylonite zones in the southern part, which are less than several tens of meters thick, were formed during the later phase of the $\mathrm{D}_{3}$-stage. The thin mylonite zones are preferentially developed within S-type tonalite and pelitic gneiss, which are characterized by a large modal amount of phyllosilicates and quartz, compared to other lithofacies in the metamorphic belt (cf. Tanaka et al., this volume).

The exhumed crustal rocks were in part modified by ductile and brittle deformations of later stages (III). After the $\mathrm{D}_{3}$-stage, sinistral-reverse-slip movement during the Ds-stage has produced very-low-temperature and thinner mylonite zones in the southernmost part of the metamorphic belt (Table 1; Obara and Toyoshima, 2000). Most of 


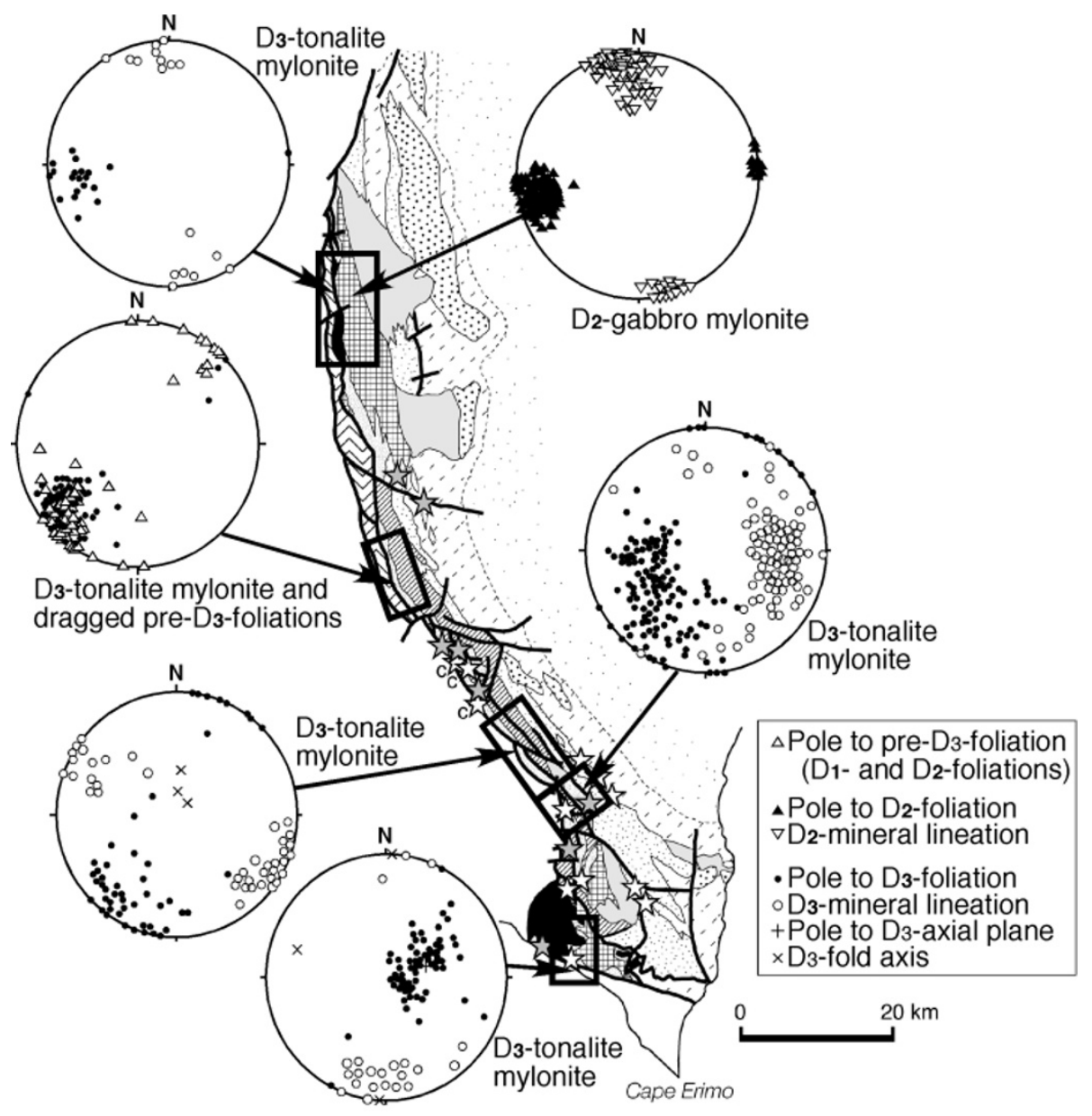

Fig. 2. Lower hemisphere equal area projections showing structural data of $D_{2}$-mylonite, $D_{3}$-mylonite, and dragged pre- $D_{3}$-foliations parallel to the western-margin mylonite zone within the Hidaka metamorphic belt. The northern and southern parts of the metamorphic belt are characterized by steeply eastward inclined homocline and complicated and low-angle structures, respectively.

the Ds-mylonites resulted from reactivation of $\mathrm{D}_{3}$-thin mylonite zones. After the Ds-stage, sinistral shearing gave rise to asymmetric kink folds (Dk-stage), and then conjugate strike-slip faulting resulted in the formation of the layeroblique pseudotachylytes (Dpt-stage; Toyoshima, 1990; Toyoshima et al., 1997). The conjugate fault set, which cut the general trend of the metamorphic belt highly obliquely, was formed under ENE-WSW compression during the latest Miocene.

\section{Distribution and Structural Characteristics of the Hidaka Pseudotachylytes}

Two structural types of the pseudotachylytes are distinguished in the Hidaka crustal rocks: layer-parallel and layer-oblique pseudotachylytes. These Hidaka pseudotachylytes show neither $\mathrm{D}_{3}$ - nor Ds-mylonitic foliations.

The layer-oblique pseudotachylytes are scattered in the metamorphic belt (Fig. 1) and occur together with thick cataclasite zones. The pseudotachylyte-generating faults have ENE-WSW to WNW-ESE or NE-SW trends and nearly vertical dips. The foliation of the host rocks of the layer-oblique pseudotachylytes is weakly to very weakly dragged parallel to the fault planes. Some layer-oblique pseudotachylytes are seen to crosscut layer-parallel pseudotachylytes, indicating the former pseudotachylyte gener- ation post-dates the latter. Some layer-oblique pseudotachylyte veins cut several other layer-oblique veins sharply, suggesting repeated pseudotachylyte-producing seismic faulting along the same fault plane. Epidote veins similar in orientations to the layer-oblique pseudotachylytes (Fig. 3) are found in the host rocks of the layer-oblique pseudotachylytes. Most of the epidote veins are cut by the layer-oblique pseudotachylytes.

Layer-parallel pseudotachylytes, which occur together with cataclasite zones with highly variable thickness, are only found in the southern part of the metamorphic belt (Fig. 1). Most of the layer-parallel pseudotachylytes are cataclasite-free to -poor and occur along biotite-rich ultramylonites and biotite-rich strongly foliated mylonites in the low-temperature and thin mylonite zones formed during the later phase of the $\mathrm{D}_{3}$-stage (Fig. 4; Shimada et al., this volume). The biotite grains have strong shape and lattice preferred orientations in the host $\mathrm{D}_{3}$-mylonites along the layer-parallel pseudotachylyte-generating faults. The $\mathrm{D}_{3}$ mylonitic foliation of the host rocks is often dragged along and cut by the layer-parallel pseudotachylyte-generating faults. Layer-parallel and cataclasite-free to -poor pseudotachylytes are not found along the very-low-temperature and thinner mylonite zones formed during the Ds-stage, and do also not occur in the major thick mylonite zones formed 


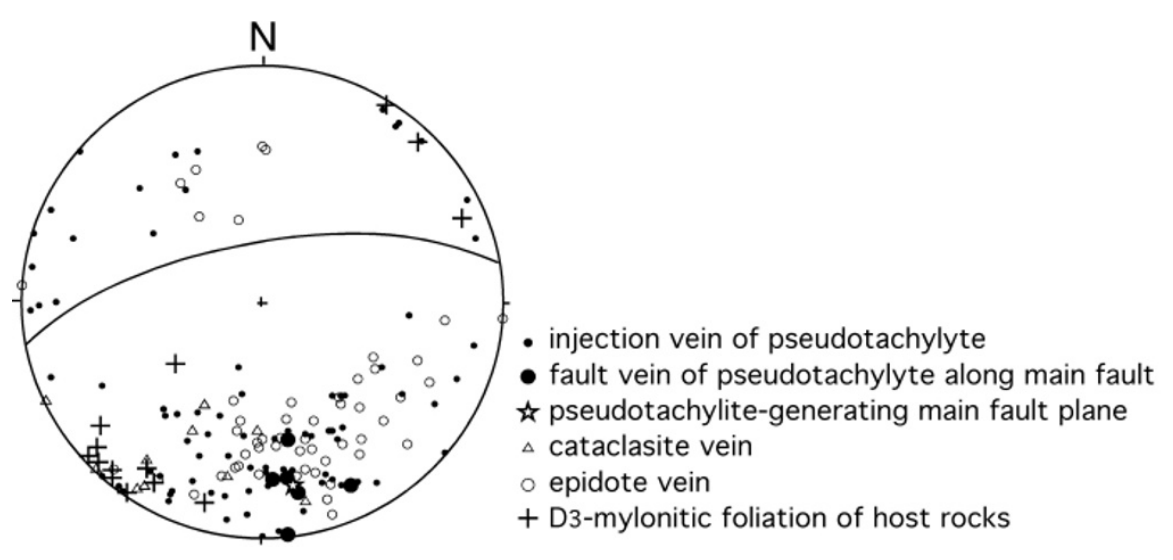

Fig. 3. Geometry of layer-oblique pseudotachylyte vein, pseudotachylyte-generating fault plane, mylonitic foliation of host rocks, and epidote vein in Soematsu-zawa River area. Great circle: pseudotachylyte-generating main fault plane.

during the $\mathrm{D}_{2}$ - and $\mathrm{D}_{3}$-stages. Some layer-parallel pseudotachylyte veins cut other layer-parallel veins sharply, suggesting repeated pseudotachylyte-producing seismic faulting along the same fault plane. The layer-parallel and cataclasite-rich pseudotachylytes are rarely found in the major $2 \mathrm{~km}$-thick western-margin mylonite zone along the Hidaka Main Thrust.

The uppermost (easternmost) layer-parallel pseudotachylytes of the metamorphic belt are found in $\mathrm{D}_{3}$-thin mylonite zones (uppermost mylonite zone) in the uppermost part of the middle tonalite body (Figs. 1 and 4). The uppermost mylonite zone, which is less than several tens of meters thick and extends to ca. $6 \mathrm{~km}$ long at maximum, contains several narrow ultramylonite zones formed under the greenschist facies conditions (Fig. 4). Asymmetric microstructures such as S-C fabrics and mantled porphyroclast systems from the uppermost mylonite zone indicate a dextral sense of shear.

Strain gradient is not regular within the $\mathrm{D}_{3}$-thin mylonite zones and $\mathrm{D}_{3}$-ultramylonites may be found in direct contact with almost non-mylonitized tonalite. The high-strain zones and ultramylonites are not necessarily in the centers of the mylonite zones (Fig. 4). The narrow layer-parallel pseudotachylytes or ultracataclasites are generally located within or at the contact of the ultramylonites (Fig. 4).

The surfaces of the layer-parallel and cataclasite-free pseudotachylyte-generating faults tend to be smooth, but the cataclasite-present pseudotachylyte-generating faults have rough surfaces. Surfaces of second-order faults relative to the uppermost layer-parallel pseudotachylytegenerating faults are irregular, defined by dark seams of opaque material with sinuous to smooth appearance and having a stylolitic aspect.

\section{Processes of Pseudotachylyte Formation}

Petrological and structural studies have shown that the layer-oblique pseudotachylytes were formed at shallow depths (ca. $4 \mathrm{~km}$ ) by strike-slip faulting under conditions of E-W maximum compressive stress after the $\mathrm{D}_{3}$ - and Dk-stages (Table 1; Toyoshima, 1990). The mode of occurrence of the layer-oblique pseudotachylytes suggests that small seismogenic areas along the conjugate strike-

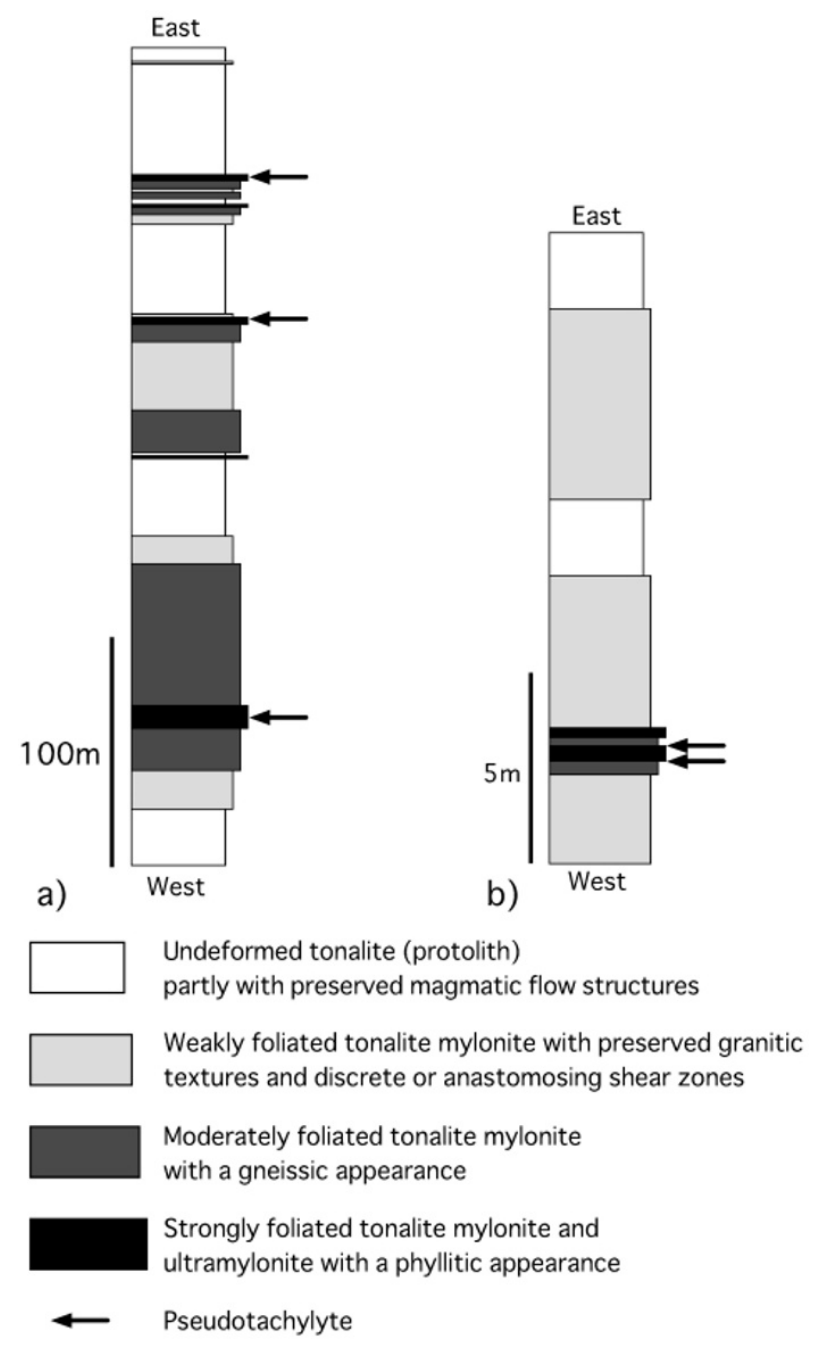

Fig. 4. Geological columnar sections showing $\mathrm{D}_{3}$-thin mylonite zones and pseudotachylyte horizons in middle S-type tonalite. a) Shimono-sawa River, an upper branch of the Horoman-gawa River, b) Rakko-gawa River.

slip faults were scattered in the metamorphic belt, and that the pseudotachylyte-producing seismic faulting occurred repeatedly in the same faults under the brittle regime. From the field relations it may be inferred that the epidote veins 
were produced by co-seismic fracturing or aseismic deformation under the same stress field as the layer-oblique pseudotachylytes.

On the basis of the present preliminary structural analysis, the layer-parallel pseudotachylytes appear to have been formed by a sinistral-slip movement before the Dpt-stage (Table 1). They are inconsistent with and post-date the $\mathrm{D}_{3}$-mylonite-generating tectonics. Furthermore, their formation may have post-dated or followed the Ds-mylonitegenerating tectonics, because they are not mylonitized but related to cataclastic deformation (Table 1).

The layer-parallel pseudotachylytes and $\mathrm{D}_{3}$-lowtemperature thin mylonite zones are particularly abundant in the southern part of the metamorphic belt which is characterized by complicated and duplicated geological structures compared to the northern part. The northern part is characterized by a simple structure: steeply eastward inclined homocline (Fig. 2). The abundance of the layer-parallel pseudotachylytes may have been possible by the formation of the complicated and duplicated crustal structures with the abundance of the $D_{3}$-thin mylonite zones. Enrichment in biotite in the $\mathrm{D}_{3}$-thin mylonites may have enhanced and controlled the formation of the layer-parallel pseudotachylytes in the southern part of the Hidaka metamorphic belt (cf. Shimada et al. and Tanaka et al., this volume). The abundance of the layer-parallel pseudotachylytes suggests that many seismic slips have occurred repeatedly in the southern part. The southern part may have been an ancient seismogenic or earthquake rupture area in the Hidaka crust, containing asperities. Radius of the area may be estimated at a few tens of kilometers (Fig. 1). The layer-parallel pseudotachylytes are interpreted to have formed in the seismogenic zone by seismic slip on the mylonitic foliation in not thick but thin plastic high-strain zones. Mode of occurrence of the layer-parallel pseudotachylytes along strong mylonitic foliation with cataclasites suggests that the rupture and melting processes have occurred at the bottom of upper crust on the top of the brittle-plastic transition zone.

\section{Conclusions}

The spatial distribution and structural characteristics of the Hidaka pseudotachylytes preliminarily suggest the following conclusions.

(1) Two structural types of the pseudotachylytes are distinguished in the Hidaka metamorphic belt: layer-oblique and layer-parallel pseudotachylytes. The layer-oblique pseudotachylytes are scattered in the metamorphic belt, but the layer-parallel pseudotachylytes occur only in the southern part of the metamorphic belt.

(2) An abundance of the layer-parallel pseudotachylytes and their host thin mylonite zones suggests that earthquakes have occurred frequently and repeatedly in the southern part of the metamorphic belt. The southern part, where complicated and duplicated geological structures occur, may represent an ancient seismogenic or earthquake rupture area containing asperities and having a radius of a few tens of kilometers in the Hidaka crust. The layer-parallel pseudotachylytes resulted from seismic slip on the mylonitic foliation within narrow plastic high-strain (mylonite) zones that have acquired strong preferred orientation of hydrous minerals. The mode of occurrence of the layer-oblique pseudotachylytes suggests that small seismogenic areas along the conjugate vertical strike-slip faults were scattered in the metamorphic belt, and that the pseudotachylyte-producing seismic faulting occurred repeatedly under the brittle regime.

(3) The layer-parallel pseudotachylytes have post-dated or followed the Ds-latest and very-low-temperature mylonitization after the $\mathrm{D}_{3}$-stage in the metamorphic belt. The formation of the layer-parallel pseudotachylytes may have been enhanced and controlled by enrichment in biotite not in the $\mathrm{D}_{3}$-major thick mylonite zones but in the later $\mathrm{D}_{3}$-low temperature thin mylonite zones of the southern part of the metamorphic belt. Subsequently the layer-oblique pseudotachylytes were formed cutting the pre-existing fault rocks. Mode of occurrence of the layer-parallel pseudotachylytes along strong mylonitic foliation with cataclasites suggests that the rupture and melting processes have occurred at the bottom of upper crust on the top of the brittle-plastic transition zone.

Acknowledgments. We wish to express our sincere thanks to two referees, Dr. K. Arita of Hokkaido University and Dr. A. M. Boullier of Laboratoire de Géophysique Interne et Tectonophysique, whose suggestions and valuable critical reviews greatly improved the manuscript. Dr. K. Fujimoto of Tokyo Gakugei University is also thanked for his helpful advice. We acknowledge Dr. Y. Osanai of Kyushu University and Dr. M. Owada of Yamaguchi University for their invaluable discussions throughout our study. Thanks are also due to the staffs of the Urakawa, Hiroo, and Shizunai local forestry offices, the Hidaka management office of the Hokkaido prefectural forest, the Samani town office, and the Samani local board of education for their kind assistance and hospitality during fieldwork. This work was partly financially supported by a Grantin-Aid for Scientific Research (No. 09640542, T. Toyoshima) from the Ministry of Education, Science and Culture, Japan, and by a grant from the Comprehensive Joint Research of the Special Coordination Founds for Promoting Science and Tecnology of the Ministry of Education, Culture, Sports, Science and Technology.

\section{References}

Allen, A. R., Mechanism of frictional fusion in fault zones, Journal of Structural Geology, 1, 231-243, 1979.

Arita, K., T. Toyoshima, M. Owada, S. Miyashita, and L. Jolivet, Tectonic movement of the Hidaka Metamorphic Belt, Hokkaido, Japan, in Geology and Tectonics of Hokkaido, Monograph of the Association for the Geological Collaboration in Japan 31, 247-263, 1986 (in Japanese with English abstract).

Grocott, J., Fracture geometry of pseudotachylite generation zones: A study of shear fractures formed during seismic events, Journal of Structural Geology, 3, 169-178, 1981.

Komatsu, M., S. Miyashita, J. Maeda, Y. Osanai, and T. Toyoshima, Disclosing of a deepest section of continental type crust up-thrust as the final event of collision of arcs in Hokkaido, north Japan, in Accretion Tectonics in the Circum-Pacific Regions, edited by M. Hashimoto and S. Uyeda, pp. 149-165, TERRAPUB, Tokyo, 1983.

Komatsu, M., S. Miyashita, and K. Arita, Composition and structure of the Hidaka metamorphic belt, Hokkaido-historical review and present status-, in Geology and Tectonics of Hokkaido, Monograph of the Association for the Geological Collaboration in Japan, 31, 189-203, 1986 (in Japanese with English abstract).

Komatsu, M., Y. Osanai, T. Toyoshima, and S. Miyashita, Evolution of the Hidaka metamorphic belt, northern Japan, in Evolution of Metamorphic Belts, edited by J. S. Daly, R. A. Cliff, and B. W. Yardley, pp. 487-493, Geological Society Special Publication, 1989.

Komatsu, M., T. Toyoshima, Y. Osanai, and M. Arai, Prograde and anatectic reactions in the deep arc crust exposed in the Hidaka metamorphic belt, Hokkaido, Japan, Lithos, 33, 31-49, 1994.

Maddock, R. H., Melt origin of fault-generated pseudotachylites demon- 
strated by textures, Geology, 11, 105-108, 1983.

Maddock, R. H., Partial melting of lithic porphyroclasts in fault-generated pseudotachylytes, Neues Jahrbuch fur Mineralogie Abhandlungen, 155, 1-14, 1986.

Niizato, T. and T. Toyoshima, Mylonitic textures, mylonite-forming tectonics, and exhumation processes in the southern part of the Hidaka metamorphic belt, Hokkaido, northern Japan, in A Study on Brittleductile Transition in Naturally Deformed Crustal Materials, edited by T. Toyoshima, Report of research project, pp. 47-58, Grant-in-Aid for Scientific Research (No. 09640542) from the Ministry of Education, Japan, 2000 (in Japanese).

Obara, T., Structural analysis and petrological study of the Hidaka metamorphic belt in the Horoman-gawa River area, Unpublished master thesis of Niigata University, 1997 (in Japanese).

Obara, T. and T. Toyoshima, Mylonitization of metamorphic and plutonic rocks of the Horoman river region in the southern part of the Hidaka metamorphic belt, Hokkaido, Japan, in A Study on Brittleductile Transition in Naturally Deformed Crustal Materials, edited by T. Toyoshima, Report of research project, pp. 59-68, Grant-in-Aid for Scientific Research (No. 09640542) from the Ministry of Education, Japan, 2000 (in Japanese).

Osanai, Y., Geology and metamorphic zoning of the Main Zone of the Hidaka Metamorphic Belt in the Shizunai River region, Hokkaido, Journal of the Geolgical Society of Japan, 91, 259-278, 1985 (in Japanese with English abstract).

Osanai, Y., K. Arita, and M. Bamba, P-T conditions of granulite-facies rocks from the Hidaka metamorphic belt, Hokkaido, Japan, Journal of the Geological Society of Japan, 92, 793-808, 1986a (in Japanese with English abstract).

Osanai, Y., S. Miyashita, K. Arita, and M. Bamba, The metamorphism and thermal structure of the collisional terrain of a continental and oceanic crusts: A case of the Hidaka metamorphic belt, Hokkaido, Japan, in Geology and Tectonics of Hokkaido, Monograph of the Association for the Geological Collaboration in Japan, 31, 205-222, 1986b (in Japanese with English abstract).

Owada, M., Geology and chemical composition of granitic rocks in the southern part of the Hidaka metamorphic belt, with special reference to cordierite-bearing granitic rocks, Journal of the Geological Society of Japan, 95, 227-240, 1989 (in Japanese with English abstract).

Shimada, K., H. Tanaka, T. Toyoshima, T. Obara, and T. Niizato, Occurrence of mylonite zones and pseudotachylyte veins around the base of the upper crust: An example from the southern Hidaka metamorphic belt, Samani area, Hokkaido, Japan, Earth Planets Space, 56, this issue, 1219-1225, 2004.

Shimura, T., Intrusion of granitic magma and uplift tectonics of the Hidaka metamorphic belt, Hokkaido, Journal of the Geological Society of Japan, 98, 1-20, 1992 (in Japanese with English abstract).

Sibson, R. H., Generation of pseudotachylyte by ancient seismic faulting, Royal Astronomical Society of London Journal, 43, 775-794, 1975.

Sibson, R. H., Fault rocks and fault mechanisms, Journal of the Geological Society, London, 133, 191-213, 1977.

Spray, J. G., Artificial generation of pseudotachylyte using friction welding apparatus: Simulation of melting on a fault plane, Journal of Structural Geology, 9, 49-60, 1987.

Swanson, M. T., Pseudotachylite-bearing strike-slip duplex structures in the Fort Foster Brittle Zone, S. Maine, Journal of Structural Geology, 10, 813-828, 1988.

Tanaka, H., K. Shimada, T. Toyoshima, T. Obara, and T. Niizato, Heterogeneous material distribution, an important reason for generation of strainlocalized mylonite and frictional slip zones in the Hidaka metamorphic belt, Hokkaido, Japan, Earth Planets Space, 56, 1227-1234, this issue, 2004.

Toyoshima, T., Pseudotachylite from the main zone of the Hidaka metamorphic belt, Hokkaido, northern Japan, Journal of Metamorphic Geology, 8, 507-523, 1990.

Toyoshima, T., Tectonic evolution of the Hidaka metamorphic belt and its implication in late Cretaceous-middle Tertiary tectonics of Hokkaido, Japan, Journal of the Faculty of Science, Niigata University, Series E, $\mathbf{8}$, 1-107, 1991.

Toyoshima, T., M. Komatsu, and T. Shimura, Tectonic evolution of lower crustal rocks in an exposed magmatic arc section in the Hidaka metamorphic belt, Hokkaido, northern Japan, The Island Arc, 3, 182-198, 1994.

Toyoshima, T., M. Komatsu, and T. Shimura, Tectonics of the Hidaka metamorphic belt, Hokkaido, northern Japan, Memoirs of Geological Society of Japan, 47, 259-277, 1997 (in Japanese with English abstract).

Ueda, H., M. Kawamura, and K. Iwata, Occurrence of the Paleocene radiolarian fossils from the Idon'nappu Belt, central part of Hokkaido, Northern Japan, Journal of the Geological Society of Japan, 99, 565568, 1993 (in Japanese).

T. Toyoshima (e-mail: ttoyo@geo.sc.niigata-u.ac.jp), T. Obara, T. Niizato, H. Tanaka, K. Shimada, M. Komatsu, Y. Wada, and T. Koyasu 